OPEN

SUBJECT AREAS:

CLIMATE CHANGE

BIOGEOCHEMISTRY

Received

28 July 2014

Accepted

12 November 2014

Published

28 November 2014

Correspondence and requests for materials should be addressed to W.P.Y. (yuanwpcn@

126.com) or W.J.D. (dongwj@bnu.edu.cn)

\section{Inclusion of soil carbon lateral movement alters terrestrial carbon budget in China}

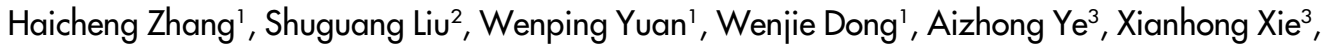 \\ Yang Chen', Dan Liu', Wenwen Cai' \& Yuna Mao ${ }^{3}$
}

\begin{abstract}
${ }^{1}$ State Key Laboratory of Earth Surface Processes and Resource Ecology, Beijing Normal University, Beijing 100875, China, ${ }^{2}$ State Engineering Laboratory of Southern Forestry Applied Ecology and Technology, Central South University of Forestry and Technology, Changsha, Hunan 410004, China, ${ }^{3}$ College of Global Change and Earth System Science, Beijing Normal University, Beijing 100875, China.
\end{abstract}

The lateral movement of soil carbon has a profound effect on the carbon budget of terrestrial ecosystems; however, it has never been quantified in China, which is one of the strongest soil erosion areas in the world. In this study, we estimated that the overall soil erosion in China varies from 11.27 to $18.17 \mathrm{Pg} \mathrm{yr}^{-1}$ from 1982 to 2011, accounting for 7-21\% of total soil erosion globally. Soil erosion induces a substantial lateral redistribution of soil organic carbon ranging from 0.64 to $1.04 \mathrm{PgC}^{-1}$. The erosion-induced carbon flux ranges from a $0.19 \mathrm{Pg} \mathrm{C} \mathrm{yr}^{-1}$ carbon source to a $0.24 \mathrm{Pg} \mathrm{C} \mathrm{yr}^{-1}$ carbon sink in the terrestrial ecosystem, which is potentially comparable in magnitude to previously estimated total carbon budget of China ( 0.19 to $\left.0.26 \mathrm{Pg} \mathrm{yr}^{-1}\right)$. Our results showed that the lateral movement of soil carbon strongly alters the carbon budget in China, and highlighted the urgent need to integrate the processes of soil erosion into the regional or global carbon cycle estimates.

T

he rapid increase in the atmospheric concentration of carbon dioxide $\left(\mathrm{CO}_{2}\right)$ has raised concerns regarding the identification of carbon sources and sinks ${ }^{1-3}$. Numerous attempts have been made to quantify the location and magnitude of terrestrial ecosystem carbon sinks ${ }^{4-6}$. However, the latest IPCC (AR5) report highlighted that some important processes are still missing in terrestrial carbon estimations ${ }^{7}$. Soil carbon lateral movement at the land surface, which represents one of the most important processes in the global carbon cycle induced by soil erosion, is poorly or not represented at all in the current carbon cycle models of earth system models that are widely used to predict future climate change ${ }^{8-9}$, and this potentially results in large uncertainties in our knowledge of terrestrial carbon sink patterns.

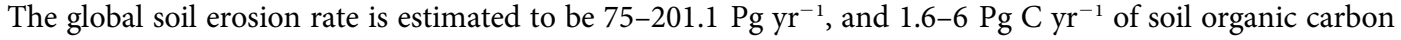
(SOC) is redistributed simultaneously ${ }^{10-13}$. The detachment, transport and deposition processes of SOC strongly regulate the magnitude of terrestrial carbon sink or source by changing three carbon exchange processes ${ }^{12,14}$. First, soil erosion may accelerate soil degradation at eroding sites and reduce plant production and available SOC for decomposition ${ }^{15,16}$. Second, deep burial of allochthonous and autochthonous SOC inhibits decomposition upon burial at deposition sites ${ }^{17-19}$. Third, the chemical or physical breakdown of soil at the detachment and transport processes increases decomposition of $\mathrm{SOC}^{12}$.

China is one of the strongest soil erosion areas, and its area-average rate of soil erosion is approximately $14.7 \mathrm{t}$ $\mathrm{ha}^{-1} \mathrm{yr}^{-1}$, which is approximately 1.44 times of the global average erosion rate $\left(10.2 \mathrm{tha}^{-1} \mathrm{yr}^{-1}\right)^{11}$. More than 3.67 $\times 10^{6} \mathrm{~km}^{2}$,or approximately $38 \%$ of the country land area, often experiences severe soil erosion ${ }^{20,21}$. The Loess Plateau and Himalayan-Tibetan regions are considered the global hot spots of soil erosion ${ }^{11,12,22}$, and the erosion rate in Loess Plateau generally ranges from 50 to $200 \mathrm{tha}^{-1} \mathrm{yr}^{-1}$.

Although the substantial impacts of soil erosion on the lateral redistribution of SOC in China have been highlighted $^{9,23}$, few studies have quantified erosion-induced changes of carbon flux between soil and the atmosphere. In the present study, we calculated the lateral displacement of soil in China using the Revised Universal Soil Loss Equation (RUSLE) ${ }^{24}$. Based on the soil erosion rate, we then estimated the lateral redistribution rate of SOC and the potential impacts of erosion on the soil carbon budget. Our main objectives were to quantify lateral redistribution rate of soil and SOC caused by water erosion in China, investigate spatiotemporal pattern of the erosion, and estimate erosion-induced carbon fluxes between the soil and atmosphere. 


\section{Results}

In order to investigate the performance of RUSLE, we collected 68 observations and simulations of erosion rate over the entire China from 1982 to 2010 (Table S1). RUSLE model explained about 79\% of the variation of soil erosion rate across all these sites (Fig. 1). On average, the RUSLE just underestimated the soil erosion rates in China by $5.3 \pm 12.2 \%$ (Fig. 1).The simulations showed that substantial amounts of soil were eroded by water over the entire country of China. The overall annual eroded soil in China varied from 11.27 to 18.17 $\mathrm{Pg} \mathrm{yr}^{-1}$, with a mean value of $15.41 \mathrm{Pg} \mathrm{yr}^{-1}$ (Fig. 2a). Severe erosion-induced redistributions of the surface soil occurred in areas of steep slopes and high-relief topography (e.g., the Tibetan Plateau), and their erosion rates generally ranged from 5 to $40 \mathrm{Mg} \mathrm{ha}^{-1} \mathrm{yr}^{-1}$. Southwestern China and the Loess Plateau in central China suffered from the strongest soil erosion, where erosion rates exceeded $40 \mathrm{Mg}$ $\mathrm{ha}^{-1} \mathrm{yr}^{-1}$ (Fig. 2a). In contrast, the plains in eastern China and deserts in northwestern China exhibited the lowest soil erosion rates, i.e., less than $1 \mathrm{Mg} \mathrm{ha}^{-1} \mathrm{yr}^{-1}$, because of low rainfall and flat terrain. Modeled total soil erosion decreased significantly $(\mathrm{p}=0.006)$ from 1982 to 2011 (Fig. 2b), likely a result of climate and land-use changes.

In combination with the spatial distribution of soil organic carbon (SOC), we simulated the lateral movement of SOC, which showed a similar spatial pattern with soil erosion. The lateral movement rates of SOC were low in the eastern plains and northwestern desert, medium in the mountainous areas and high in southwestern China and the Loess Plateau (Fig. 2b). On average, the area-average erosion rate of SOC in China was $0.094 \mathrm{MgC} \mathrm{ha}^{-1} \mathrm{yr}^{-1}$ when the enrichment ratio (ER) of SOC was set to 1.8 (median value, see Methods). The total redistributed carbon varied annually from 0.64 to $1.04 \mathrm{Pg} \mathrm{C}$

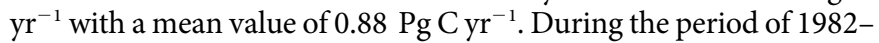
2011 , the total redistributed carbon by water erosion was estimated to be $14.83 \mathrm{Pg}$ C.

Four coefficients, derived from observations and experiments, were used to calculate the possible range of erosion-induced carbon exchange between soil and atmosphere $\left(\mathrm{E}_{\mathrm{c}}\right)$ (see Methods). $\mathrm{E}_{\mathrm{c}}$ were estimated to range from a $0.19 \mathrm{Pg} \mathrm{C} \mathrm{yr}^{-1}$ carbon source to a $0.24 \mathrm{Pg}$

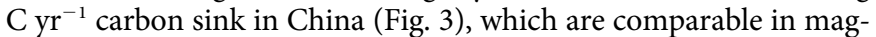
nitude to the total carbon budget of China estimated without considering the influences of lateral carbon redistribution (a sink of 0.19 to $\left.0.26 \mathrm{Pg} \mathrm{C} \mathrm{yr}^{-1}\right)^{6}$. For example, according to the first coef-

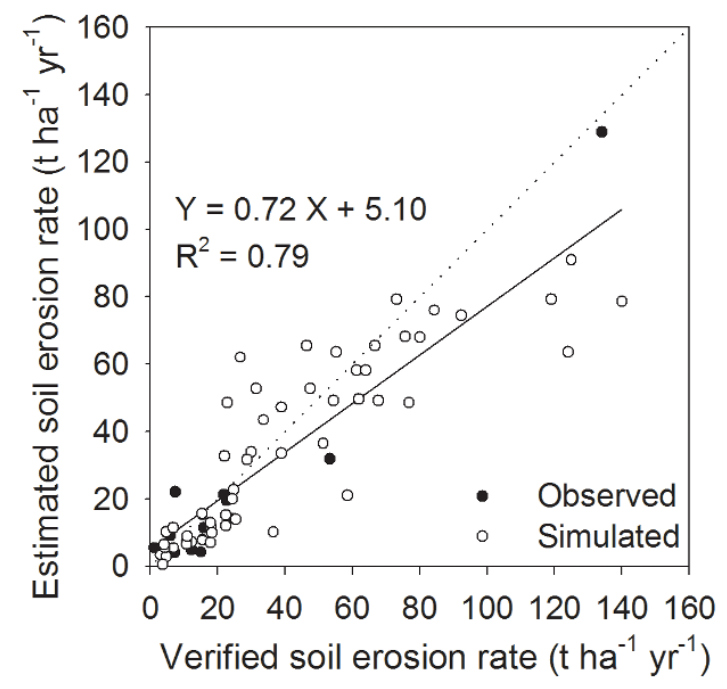

Figure 1 Comparison of estimated soil erosion rate in this study and collected observations or simulations over 68 samples (see Table S1). The dotted line is $1: 1$ line, and the solid line is regression line. All of 68 samples distributed in 28 sites. Twelve samples (solid circles) were field observations, and the remaining 56 samples (open circles) were previous model simulations. ficient $^{12,19,25}$, which assumed $20 \%$ of eroded SOC decomposed to atmosphere, lateral carbon movement would induce a 0.13$0.24 \mathrm{Pg} \mathrm{C} \mathrm{yr}^{-1}$ carbon source (Table 1), which is nearly equivalent to the estimated terrestrial carbon sink over the entire China.

\section{Discussion}

The potential impacts of soil erosion on the biogeochemical cycling of carbon remain one of the large uncertainties in our knowledge of global climate change ${ }^{9,26}$. In recent years, it has increasingly been recognized that lateral fluxes induced by soil erosion are of key importance in the global carbon budget estimates ${ }^{37}$. This study used the empirical RUSLE model to simulate the spatial and temporal patterns of soil erosion and the redistribution of SOC in China, and the results were comparable to previous estimates ${ }^{11,13,27}$. The estimated mean area-average erosion rates in China from 1982 to 2011 ranged from 11.7 to $18.9 \mathrm{Mg} \mathrm{ha}^{-1} \mathrm{yr}^{-1}$ and were consistent overall with the estimation by Yang et al. (14.7 $\mathrm{Mg} \mathrm{ha}^{-1} \mathrm{yr}^{-1}$ in 1980 s, 2003 $)^{11}$. The mean annual eroded soil and redistributed carbon were estimated to be $15.41 \mathrm{Pg} \mathrm{yr}^{-1}$ and $0.88 \mathrm{Pg} \mathrm{C} \mathrm{yr}^{-1}$, respectively, and China therefore would contribute $7-21 \%$ to the global total of soil erosion ${ }^{10,13,19}$ and $14-21 \%$ of the global redistributed SOC ${ }^{12}$. However, as the verification suggested a mean underestimation of soil erosion rate by $5.3 \%$ in China (Fig. 1), the mean annual eroded soil and carbon were potentially underestimated by $0.82 \mathrm{Pg} \mathrm{yr}^{-1}$ and $0.05 \mathrm{Pg} \mathrm{C} \mathrm{yr}^{-1}$, respectively. Moreover, due to the limited observations, most of the validation sites are located in areas that are prone to erosion, such as Karst regions and Loess Plateau; thus the verified data may not be able to fully represent the soil erosion rates across China. Therefore, more studies in the other areas of China would be benefit for quantifying the impacts of lateral redistribution of soil carbon on carbon budget.

Although it has been highlighted that lateral transportation of SOC could substantially alter ecosystem carbon budget, there are still scientific disagreements concerning the role of erosion-induced carbon changes in ecosystem carbon budget ${ }^{28,29}$. Stallard $(1998)^{15}$ estimated a net carbon sink of $0-2.0 \mathrm{Pg} \mathrm{C} \mathrm{yr}^{-1}$ by the processes of carbon burial and dynamic replacement. Using ${ }^{137} \mathrm{Cs}$ and carbon inventory measurements from a large-scale survey in Europe and North America, Van Oost et al. (2007) ${ }^{14}$ found consistent evidence for an erosion-induced sink of atmospheric carbon equivalent to approximately $26 \%$ of the lateral transported carbon by soil erosion. On the contrary, Lal $(2003)^{12}$ suggested that the accelerated mineralization of SOC, primarily due to the breakdown of aggregates, could represent a globally significant source of atmospheric carbon $\left(0.8-1.2 \mathrm{Pg} \mathrm{C} \mathrm{yr}^{-1}\right)$. There is still no model that explicitly simulates the impacts of soil lateral movement on the terrestrial carbon budget due to difficulties in accounting for many complicated processes.

More soil erosion experiments and measurements over large areas would be helpful in investigating the impact mechanisms of soil erosion on the carbon budget. However, this was not the focus of this study. Instead, we used four experience coefficients to quantify the impacts of lateral movement of soil carbon on carbon fluxes. Although it is still difficult to determine whether erosion-induced carbon fluxes between soil and the atmosphere $\left(\mathrm{E}_{\mathrm{c}}\right)$ is a carbon source or sink, the $\mathrm{E}_{\mathrm{c}}$ in China is estimated to be considerable that could significantly change the carbon budget estimate in China (Fig. 3). Although, it is still difficult to determine the nature of erosioninduced carbon budget, there is very high confidence that lateral soil carbon movement substantially alters the carbon budget of terrestrial ecosystems.

Moreover, it should be noticed that the decreased trend of soil erosion from 1981 to 2010 might substantially decrease lateral movement of soil carbon (Fig. 2b). The ecological projects in China, such as "Three-North Shelterbelt Project" and "Grain for Green Project", play an important role in decreasing the soil erosion by increasing fraction of vegetation cover since the end of $1970 \mathrm{~s}^{30,31}$. A recent forest 


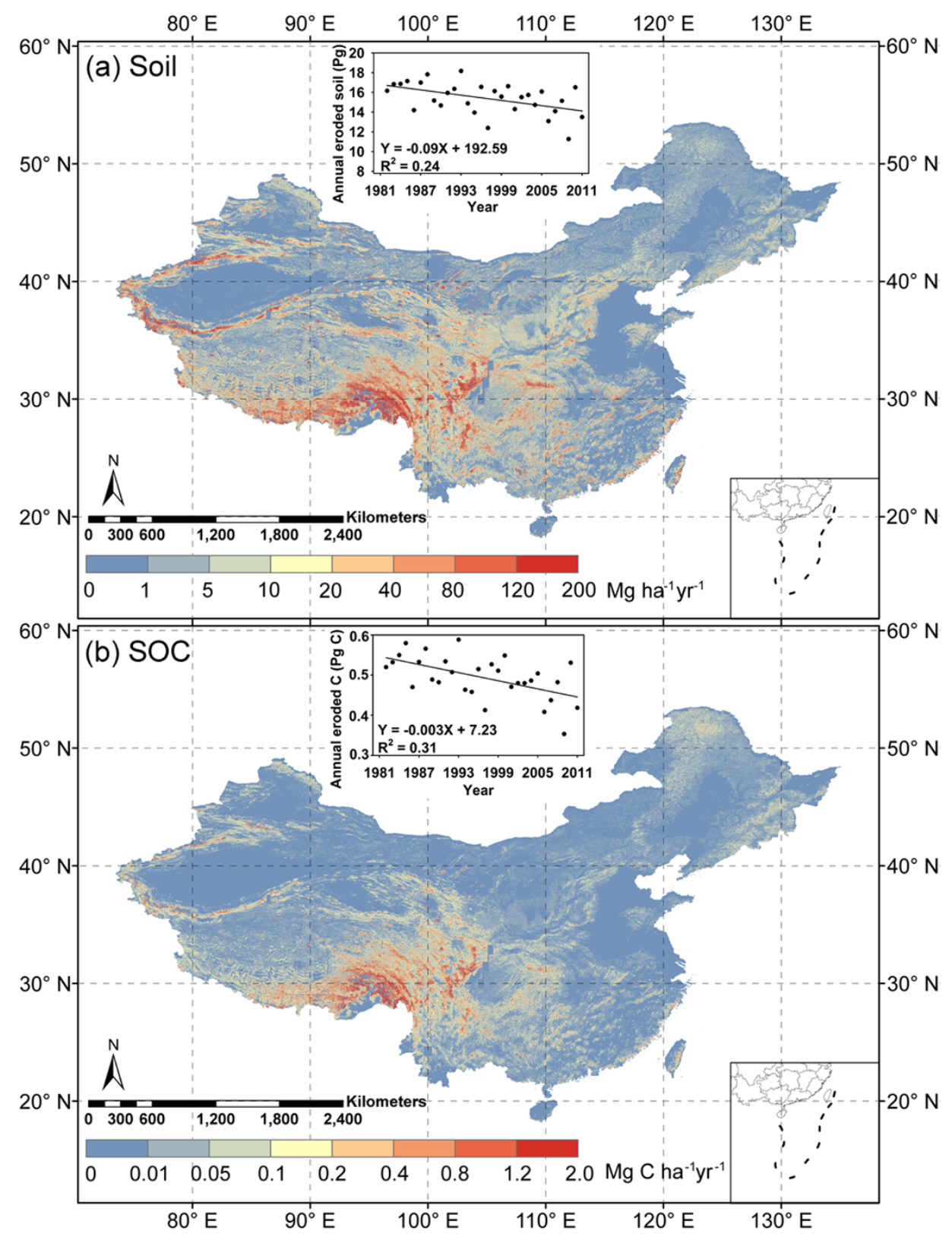

Figure 2 Simulated spatial patterns of the soil erosion rates (a) and lateral redistribution rates of soil organic carbon (SOC, b) in China, presented as the mean values from 1982 to 2011. The scatter plots show the annually total amounts of eroded soil and SOC in China. The lateral redistribution rates of SOC presented here were calculated with an enrichment ratio of 1.8. The maps were created by the ArcMap 9.3.

survey showed Asia was the only region to show net gains in forest area, chiefly due to extensive reforestation and afforestation in China (FAO, 2010). When comparing two time periods, 2003-2007 and 1998-2002, runoff and soil erosion reduced by $18 \%$ and $45.4 \%$ over 11 river systems in China due to conversion from cropland to forestland, respectively ${ }^{30}$.

Future studies need integrate soil erosion processes into ecosystem carbon cycle model to reduce the uncertainties in estimating erosioninduced ecosystem carbon fluxes. As suggested in previous studies, SOC content of the topsoil at eroding sites are determined by the erosion rate and replacement rate with new photosynthate ${ }^{14,15,26,33}$. Generally, severe erosion results in soil degradation and depletes SOC content ${ }^{12}$. Climate change and anthropogenic factors can also alter SOC content ${ }^{22,34}$. For example, ecological projects and soil conservation measures have maintained or even promoted SOC contents in many regions of China ${ }^{35}$. An estimation considering the dynamic replacement of SOC and plant production will further reduce the uncertainties. Furthermore, previous studies usually consider merely the fate of eroded SOC and ignore the changes in decomposition rate of residual SOC and vegetation production ${ }^{16,33,36}$. This may result in a one-sided estimation of the erosion-induced ecosystem carbon fluxes. Ecosystem carbon cycle models are proper means to simulate dynamics of vegetation production and SOC decomposition ${ }^{37,38}$; therefore, incorporating of soil erosion processes into ecosystem models is urgently needed to improve estimation of erosion-induced ecosystem carbon fluxes.

Moreover, processes-based models also need integrate several major soil carbon transport and decomposition processes ${ }^{39-42}$. Runoff can disintegrate soil aggregates and transport SOC of topsoil away from eroded areas ${ }^{43,44}$. Then, some SOC will be transferred to aquatic ecosystems (i.e. rivers, lakes and oceans) and the remaining part deposits in adjacent land surfaces ${ }^{15,25}$. During these processes, detachment and transport of soil lead to breakdown of structural aggregates and exposure of the hitherto encapsulated SOC within 


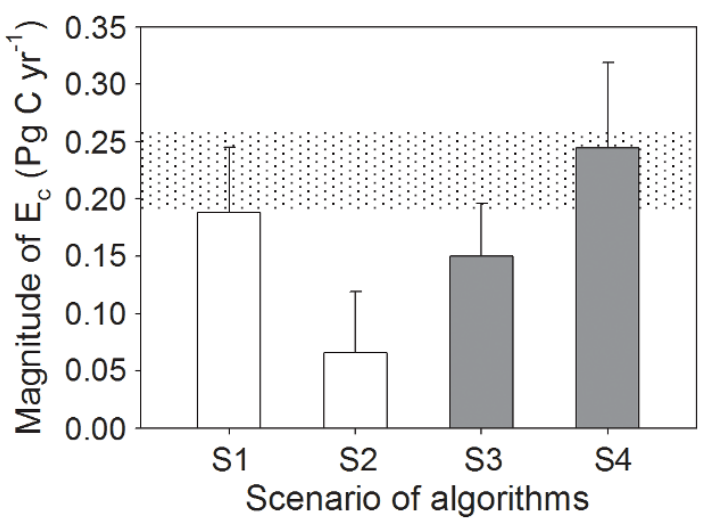

Figure 3 Erosion-induced carbon fluxes between soil and atmosphere $\left(\mathrm{E}_{\mathrm{c}}\right)$ in China. The open bars $(\mathrm{S} 1, \mathrm{~S} 2)$ denote the carbon sources of atmospheric carbon, and the gray bars (S3, S4) denote the carbon sinks of atmospheric carbon. The error bars denote the standard deviations of annual $\mathrm{E}_{\mathrm{c}}$. The dotted shade denotes the range of the total terrestrial carbon sink in China (0.19-0.26 $\left.\mathrm{Pg} \mathrm{C} \mathrm{yr}^{-1}\right)$ estimated by Piao et al. (2009) without considering the influences of soil erosion.

the aggregates to microbial processes. This will induce an attendant increase in mineralization and emission of $\mathrm{CO}_{2}{ }^{25,45}$. Nevertheless, the decomposition of SOC in depositional areas may be substantially constrained by anaerobic conditions ${ }^{46}$. Moreover, the delivery and fate of eroded SOC depend strongly on topography, soil properties, vegetation cover, and magnitude and regime of precipitation, and generally show dramatic spatiotemporal variations ${ }^{12,33}$. SOC delivered to aquatic systems may be rapidly mineralized ${ }^{12,47,48}$ or preserved in riverine, lacustrine and oceanic sediments for a long time ${ }^{17,49,50}$.It is still difficult to quantify the mineralization of transported carbon and the fate of carbon deposited in low land and aquatic systems.

In addition to water erosion, wind erosion, tillage erosion and the soil vertical movement should also be considered when estimating the ecosystem carbon budget in China ${ }^{51-53}$. The annually redistributed SOC in China due to wind erosion was estimated to be $0.075 \mathrm{Pg}$ $\mathrm{C} \mathrm{yr}^{-151}$, which is about $10 \%$ of the displaced SOC due to water

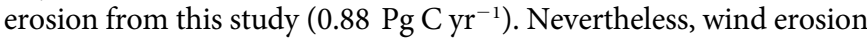
may impact carbon budget in China significantly, especially in northwestern China ${ }^{51}$. In south China, especially the Karst regions, soil vertical movement is believed to play an important role in soil-atmosphere carbon flux ${ }^{53}$. With the vertical movements of soil and water, considerable $\mathrm{CO}_{2}$ can be dissolved in water and the dissolution of calcium carbonate can result in significant carbon uptake from atmosphere. Due to the deposition of dissolved carbonate minerals caused by soil vertical movement, the Karst regions are often a net carbon $\operatorname{sink}^{53,54}$. Overall, both the lateral soil movement induced by water, wind and tillage, and the vertical soil movement should be integrated to carbon cycle modeling for quantifying regional or global ecosystem carbon budgets.

\section{Methods}

Revised Universal Soil Loss Equation. The water erosion rate in China was calculated using the Revised Universal Soil Loss Equation (RUSLE) ${ }^{24}$. The RUSLE is the most popular empirically based model that is used for erosion prediction and control $^{55}$, and it has been tested in many watersheds worldwide. Although it is an empirical model for accessing long-term averages of sheet and rill erosion, the calculation of its factors can be improved and adapted to enable application to various spatial scales in different environments ${ }^{56,57}$. Generally, the formulation of RUSLE is expressed as

$$
\mathrm{A}=\mathrm{R} \times \mathrm{K} \times \mathrm{L} \times \mathrm{S} \times \mathrm{C} \times \mathrm{P}
$$

where $\mathrm{A}$ is the annual potential soil erosion rate $\left(\mathrm{t} \mathrm{ha}^{-1} \mathrm{yr}^{-1}\right)$; $\mathrm{R}$ is the rainfall-runoff erosivity factor ( $\mathrm{MJ} \mathrm{mm} \mathrm{ha}{ }^{-1} \mathrm{~h}^{-1} \mathrm{yr}^{-1}$ ); $\mathrm{K}$ is the soil erodibility factor ( $\mathrm{t} \mathrm{ha} \mathrm{h} \mathrm{ha}{ }^{-1} \mathrm{MJ}^{-1}$ $\left.\mathrm{mm}^{-1}\right)$; $\mathrm{L}$ is the slope length factor; $\mathrm{S}$ is the slope steepness factor; $\mathrm{C}$ is the covermanagement factor; $\mathrm{P}$ is the support practice factor.

$\mathrm{R}$, the rainfall-runoff erosivity factor, is computed originally from rainfall amount and intensity. Here we used a regression relationship to calculate $\mathrm{R}$ factor $^{14,58}$ :

$$
\mathrm{R}=0.0483 \mathrm{P}_{\mathrm{a}}^{1.610}
$$

where $\mathrm{P}_{\mathrm{a}}$ is the total annual precipitation $(\mathrm{mm})$.

$\mathrm{K}$, the erodibility factor was calculated according to the method in EPIC $\operatorname{model}^{59}$ :

$$
\begin{gathered}
\mathrm{K}=\frac{1}{7.59}\left\{0.2+0.3 \exp \left[-0.0256 \mathrm{SAN}\left(1-\frac{\mathrm{SIL}}{100}\right)\right]\right\}\left(\frac{\mathrm{SIL}}{\mathrm{CLA}+\mathrm{SIL}}\right)^{0.3} \\
\left(1.0-\frac{0.25 \mathrm{OM}}{\mathrm{OM}+\exp (3.72-2.95 \mathrm{OM})}\right)\left(1.0-\frac{0.25 \mathrm{SN}}{\mathrm{SN}+\exp (-5.51+22.9 \mathrm{SN})}\right) \\
\mathrm{SN}=1.0-\frac{\mathrm{SAN}}{100}
\end{gathered}
$$

where SAN, SIL and CLA are the percentage content (\%) of sand, silt and clay, respectively. OM is the content of SOC (\%).

The slope length factor (L) and slope steepness factor (S) reflect the effect of topography on soil erosion in RUSLE. We extracted the original slope length $(\lambda)$ and steepness $(\beta)$ from the digital topography map of China ( $5^{\prime}$ resolution) using the algorithm proposed by Van Remortel et al. $(2004)^{60}$. Then, the slope length factor was calculated by

$$
\begin{gathered}
\mathrm{L}=\left(\frac{\lambda}{22.13}\right)^{\mathrm{m}} \\
\mathrm{m}=\frac{\mathrm{F}}{1+\mathrm{F}} \\
\mathrm{F}=\frac{\sin \beta}{0.0896\left[3(\sin \beta)^{0.8}+0.56\right]}
\end{gathered}
$$

The slope steepness factor (S) was calculated from

$$
S=\left\{\begin{array}{l}
10.8 \sin \beta+0.03, \beta<5 \\
10.8 \sin \beta-0.50, \beta \geq 5
\end{array}\right.
$$

To reduce the bias and random errors, the slope factors derived on a 5-minute resolution were then aggregated to a resolution of $0.01^{\circ}$.

$\mathrm{C}$, the cover-management factor, is used to reflect the effect of cropping and

\begin{tabular}{|c|c|c|c|c|c|c|c|c|c|c|}
\hline ER & $\mathrm{T}_{\mathrm{c}}\left(\mathrm{Pg} \mathrm{Cyr}^{-1}\right)$ & \multicolumn{4}{|c|}{$E_{c}\left(P g C y r^{-1}\right)$} & $\mathrm{T}_{\mathrm{ac}}(\mathrm{Pg} \mathrm{C})$ & \multicolumn{4}{|c|}{$E_{a c}(P g C)$} \\
\hline $\begin{array}{l}1.3 \\
1.8 \\
2.6\end{array}$ & $\begin{array}{l}0.64 \\
0.88 \\
1.19\end{array}$ & $\begin{array}{l}-0.13 \\
-0.17 \\
-0.24\end{array}$ & $\begin{array}{l}-0.08--0.01 \\
-0.10--0.02 \\
-0.14--0.02\end{array}$ & $\begin{array}{l}0.10 \\
0.14 \\
0.19\end{array}$ & $\begin{array}{l}0.17 \\
0.22 \\
0.31\end{array}$ & $\begin{array}{l}19.26 \\
25.70 \\
35.70\end{array}$ & $\begin{array}{l}-3.85 \\
-5.14 \\
-7.14\end{array}$ & $\begin{array}{l}-2.31--0.39 \\
-3.08--0.51 \\
-4.28--0.71\end{array}$ & $\begin{array}{l}3.08 \\
4.11 \\
5.71\end{array}$ & $\begin{array}{r}5.02 \\
6.95 \\
10.04\end{array}$ \\
\hline
\end{tabular}
management practices on soil-erosion rates ${ }^{24}$. Here, the method proposed by Yang and Shi $(1994)^{61}$, often been used widely in China for estimating regional soil losses ${ }^{57,62,63}$, was adopted to calculate the $\mathrm{C}$ factor:

Table 1 Simulated lateral redistributed soil organic carbon (SOC) and erosion-induced carbon flux between soil and atmosphere in China from 1982 to 2011 . ER is the enrichment ratio of $S O C ; T_{c}$ is the mean annual redistributed $S O C ; E_{c}$ is the mean annual erosion-induced $C$ flux between soil and atmosphere; $T_{a c}$ is the accumulated redistributed $S O C$ through 1982 to 2011 ; $E_{a c}$ is the accumulated erosion-induced $C$ flux between soil and atmosphere. The positive $\mathrm{E}_{\mathrm{c}}$ and $\mathrm{E}_{\mathrm{ac}}$ denote sinks of atmospheric carbon and the negative values denote sources of atmospheric carbon. S1, S2, S3 and S4 indicate the 4 different scenarios (see Methods) 


$$
\begin{gathered}
\mathrm{f}_{\mathrm{VC}}=\frac{\mathrm{NDVI}_{\mathrm{i}}-\mathrm{NDVI}_{\text {soil }}}{\mathrm{NDVI}_{\mathrm{veg}}-\mathrm{NDVI}_{\text {soil }}} \\
\mathrm{C}=\left\{\begin{array}{cl}
1, & \mathrm{fvc}=0 \\
0.658-0.3436 \log (\mathrm{fvc}), & 0<\mathrm{fvc}<78.3 \% \\
0, & \mathrm{fvc} \geq 78.3 \%
\end{array}\right.
\end{gathered}
$$

where $\mathrm{NDVI}_{\mathrm{i}}$ is the actual annual average normalized difference vegetation index (NDVI); $\mathrm{NDVI}_{\text {soil }}$ the NDVI of uncovered, bare ground; $\mathrm{NDVI}_{\mathrm{veg}}$ is the NDVI of ground completely covered by vegetation; and fvc is the annual average fraction vegetation cover $(\%)$

$\mathrm{P}$, the support practice factor, is the ratio of soil loss with a support practice such as contouring, or terracing to soil loss without support practice. Because there is no support practice on most land in China, except for some farmlands on steep slopes, a constant value of 1.0 was applied for $\mathrm{P}$.

This study used the digital elevation model (ASTER GDEM) with $90 \mathrm{~m}$ resolution to drive RUSLE model (downloaded from ASTER GDEM, http://www.gdem.aster. ersdac.or.jp). We collected meteorology data of 750 stations from the National Climate Center of China Meteorological Administration. The thin plate smoothing splines method was used to generate the daily precipitation for all of China at a spatial resolution of $25 \mathrm{~km}$ of latitude and longitude for the period of 1982-2011 $1^{64}$. Soil texture (e.g., sand and clay content) and soil carbon content data with spatial resolution of $0.0083^{\circ}$ latitude $\times 0.0083^{\circ}$ longitude were obtained from Shang-Guan et al $(2012)^{65}$. We uses the biweekly NDVI data with an 8 - $\mathrm{km}$ spatial resolution covering the period from 1982 to 2011 from Global Inventory Monitoring and Modeling Studies (GIMMS-3g) (20). All of the RUSLE factors derived from these databases were resampled to a resolution of $0.01^{\circ}$

Erosion-induced carbon budget. The erosion rate of $\operatorname{SOC}\left(\mathrm{T}_{\mathrm{C}}\right)$ was calculated as:

$$
\mathrm{T}_{\mathrm{c}}=\mathrm{A} \times \mathrm{C}_{\mathrm{SOC}} \times \mathrm{ER}
$$

where $\mathrm{C}_{\mathrm{soc}}$ is the $\mathrm{SOC}$ content in the $0-30 \mathrm{~cm}$ soil layer (\%). We assumed that the spatially distributed SOC content remained fairly stable during the period from 1982 to 2011. The enrichment ratio (ER) is defined as the ratio of the SOC content in the eroded soils to that of the parent soils ${ }^{42,66}$. Currently, there are disagreements regarding $\mathrm{ER}^{14,67}$. Many studies have suggested a value higher than unity for ER because SOC is of relatively low density and concentrated in the vicinity of the soil surface ${ }^{12,68}$. However, several studies have reported ER values equal to or less than the unit because part of SOC had been decomposed during the transport process or rill erosion had occurred in deep subsoil, resulting in very low SOC content ${ }^{9,69}$. The measurements obtained globally from previous studies showed that ER varied drastically among different environments ${ }^{33,70}$. In this study, we collected 55 ER observations globally (Table S2), and determined the median, $25^{\text {th }}$ percentile and $75^{\text {th }}$ percentile values of ER were 1.8, 1.3 and 2.6, respectively.

There is still no ideal method that can be used to identify the net impacts of soil erosion on soil-atmosphere carbon flux ${ }^{28,71}$. We used four scenarios, derived from field and control experiments, to calculate carbon exchange between ecosystem and atmosphere induced by soil carbon lateral movement. (1) Lal $(1995,2003,2004)^{12,19,25}$ made an empirical assumption that $20 \%$ of the eroded SOC would be decomposed and subsequently emitted to the atmosphere, based on literature surveys. (2) Based on the laboratory experiments, Van Hemeleyck et al. (2009 ${ }^{29}$ suggested that soil erosion would contribute additional carbon emissions of 2 to $12 \%$ of the total eroded carbon. (3) According to the study at two watersheds of western America, soil erosion would increase ecosystem carbon sink about $16 \%$ of the total eroded $\mathrm{C}^{26}$. (4) The erosioninduced carbon budget would be a sink of $26 \%$ of the total eroded carbon according to carbon inventory measurements by large-scale survey in America and Europe ${ }^{14}$.

1. Schimel, D. S. et al. Recent patterns and mechanisms of carbon exchange by terrestrial ecosystems. Proc Natl Acad Sci USA 414, 169-172 (2001).

2. Houghton, R. A. Balancing the global carbon budget. Annu Rev Earth Planet Sci 35, 313-347 (2007).

3. Abril, G. et al. Amazon river carbon dioxide outgassing fuelled by wetlands. Nature 505, 395-398 (2013).

4. Schimel, D. S. Terrestrial ecosystems and the carbon cycle. Global Change Biol 1, 77-91 (1995).

5. Janssens, I. A. et al. Europe's terrestrial biosphere absorbs 7 to $12 \%$ of European anthropogenic $\mathrm{CO}_{2}$ emissions. Science 300, 1538-1542 (2003).

6. Piao, S. et al. The carbon balance of terrestrial ecosystems in China. Nature 458, 1009-1013 (2009).

7. Stocker, et al. IPCC: Climate Change 2013: The Physical Science Basis [Stocker, T. F. et al. (ed.)]. [1535] (Cambridge University Press, Cambridge, United Kingdom and New York, NY, USA, 2013).

8. Quinton, J. N., Govers, G., Van Oost, K. \& Bardgett, R. D. The impact of agricultural soil erosion on biogeochemical cycling. Nat Geosci 3, 311-314 (2010),

9. Ran, L., Liu, X. X. \& Xin, Z. Erosion-induced massive organic carbon burial and carbon emission in the Yellow River basin, China. Biogeosciences 11, 945-959 (2014)

10. Pimentel, D. et al. Environmental and economic costs of soil erosion and conservation benefits. Science 267, 1117-1123 (1995).
11. Yang, Y. D., Kanae, S., Oki, T., Koike, T. \& Musiake, K. Global potential soil erosion with reference to land use and climate changes. Hydrol Process 17, 2913-2928 (2003).

12. Lal, R. Soil erosion and the global carbon budget. Environ Int 29, 437-450 (2003).

13. Ito, A. Simulated impacts of climate and land-cover change on soil erosion and implication for the carbon cycle, 1901 to 2100. Geophys Res Lett 34, L09403; DOI: 10.1029/2007GL029342 (2007).

14. Van Oost, K. et al. The impact of agricultural soil erosion on the global carbon cycle. Science 318, 626-629 (2007).

15. Stallard, R. F. Terrestrial sedimentation and the carbon cycle: Coupling weathering and erosion to carbon burial. Global Biogeochem Cy 12, 231-257 (1998).

16. Harden, J. W. et al. Dynamic replacement and loss of soil carbon on eroding cropland. Global Biogeochem Cy 13, 885-901 (1999).

17. Smith, S. V., Sleeze, r R. O., Renwick, W. H. \& Buddemeier, R. Fates of eroded soil organic carbon: Mississippi basin case study. Ecol Appl 15, 1929-1940 (2005).

18. Yoo, K., Amundson, R., Heimsath, A. M. \& Dietrich, W. E. Erosion of upland hillslope soil organic carbon: Coupling field measurements with a sediment transport model. Global Biogeochem Cy 19, GB3003; DOI:10.1641/B570408 (2005).

19. Lal, R. Soil carbon sequestration impacts on global climate change and food security. Science 304, 1623-1627 (2004).

20. Zhang, P. et al. China's Forest policy for the $21^{\text {st }}$ century. Science 288, 2135-2136 (2000).

21. López-Pujol, J. \& Zhao, A. M. China: a rich flora needed of urgent conservation. Orsis 19, 49-89 (2004)

22. Chen, L. D., Wang, J., Fu, B. J. \& Qiu, Y. Land-use change in a small catchment of northern Loess Plateau, China. Agr Ecosyst Environ 86, 163-172 (2001).

23. Fu, B., Chen, L., Ma, K., Zhou, H. \& Wang, J. The relationships between land use and soil conditions in the hilly area of the loess plateau in northern Shaanxi, China. Catena 39, 69-78 (2009).

24. Renard, K. G., Foster, G. R., Weesies, G. A., McCool, D. K. \& Yoder, D. C. Predicting Soil Erosion by Water: A Guide to Conservation Planning with the Revised Soil Loss Equation (RUSLE). U.S. Dept. of Agriculture. Agriculture Handbook 703, 404 (1997).

25. Lal, R. [Global soil erosion by water and carbon dynamics] Soils and global change [Lal, R., Kimble, J. M., Levine, E., Stewart, B. A. (ed.)] [131-141] (CRC/Lewis Publishers, Boca Raton, 1995).

26. Berhe, A., Harte, J., Harden, J. \& Torn, M. The significance of the erosion-induced terrestrial carbon sink. BioScience 57, 337-346 (2007).

27. Yang, M. Y., Tian, J. L. \& Liu, P. L. Investigating the spatial distribution of soil erosion and deposition in a small catchment on the Loess Plateau of China, using ${ }^{137}$ Cs. Soil Till Res 87, 186-193 (2006).

28. Quine, T. A. \& Van Oost, K. Quantifying carbon sequestration as a result of soil erosion and deposition: retrospective assessment using caesum-137 and carbon inventories. Global Change Biol 13, 2160-2625 (2007).

29. Van Hemelryck, H., Fiener, P., Van Oost, K. \& Govers, G. The effect of soil redistribution on soil organic carbon: an experimental study. Biogeosciences $\mathbf{6}$, 5031-5071 (2009).

30. Deng, L., Shangguan, Z. \& Li, R. Effects of the grain-for-green program on soil erosion in China. Int J Sediment Res 27, 120-127 (2012).

31. Li, M. M. et al. An overview of the "Three-North" Shelterbelt project in China. For Stud China 14, 70-79 (2012).

32. Bahamondez, C. et al. Global Forest Resources Assessment 2010: main report. Food and Agriculture Organization of the United Nations (FAO), http://www.fao. org/forestry/fra/fra2010 (2010) (Date of access: 04/10/2010).

33. Liu, S. G., Bliss, N., Sundquist, E. \& Huntington, T. G. Modeling carbon dynamics in vegetation and soil under the impact of soil erosion and deposition. Global Biogeochem Cy 17, 1074; DOI:10.1029/2002GB002010 (2003).

34. Albaladejo, J. et al. Land use and climate change impacts on soil organic carbon stocks in semi-arid Spain. J. Soil Sediments 13, 265-277 (2013).

35. Feng, X., Fu, B., Lu, N., Zeng, Y. \& Wu, B. How ecological restoration alters ecosystem services: an analysis of carbon sequestration in China's Loess Plateau. Sci Rep 3, 2846; DOI:10.1038/srep02846 (2013).

36. Van Hemelryck, H., Govers, G., Van Oost, K. \& Merckx, R. Evaluating the impact of soil redistribution on the in situ mineralization of soil organic carbon. Earth Surf Proc Land 36, 427-438 (2011).

37. Sitch, S. et al. Evaluation of ecosystem dynamics, plant geography and terrestrial carbon cycling in the LPJ dynamic global vegetation model. Global Change Biol 9, $161-185$ (2003).

38. Kucharik, C. J. et al. A multiyear evaluation of a dynamic global vegetation model at three AmeriFlux forest sites: Vegetation structure, phenology, soil temperature, and $\mathrm{CO}_{2}$ and $\mathrm{H}_{2} \mathrm{O}$ vapor exchange. Ecol Model 196, 1-31 (2005).

39. Hope, D., Palmer, S. M., Billett, M. F. \& Dawson, J. J. Carbon dioxide and methane evasion from a temperate peatland stream. Limnol Oceanogr 46, 847-857 (2001).

40. Richey, J. E., Melack, J. M., Aufdenkampe, A. K., Ballester, V. M. \& Hess, L. L. Outgassing from Amazonian rivers and wetlands as a large tropical source of atmospheric $\mathrm{CO}_{2}$. Nature 416, 617-620 (2002).

41. Rodriguez, A. R. et al. Forms of eroded soil organic carbon in andosols of the Canary Islands (Spain). Geoderma 121, 205-219 (2004). 
42. Schiettecatte, W., Gabriels, D., Cornelis, W. M. \& Hofinan, G. Impact of deposition on the enrichment of organic carbon in eroded sediment. Catena $\mathbf{7 2}$, 340-347 (2008).

43. Le Bissonnais, Y. \& Arrouays, D. Aggregate stability and assessment of soil crustability and erodibility: II. Application to humic loamy soils with various organic carbon contents. Eur J Soil Sci 48, 39-48 (1997).

44. Van Oost, K., Govers, G., Quine, T. A. \& Heckrath, G. Comment on "Managing soil carbon" (I). Science 305, 1567b (2004).

45. Raymond, P. A. \& Bauer, J. E. Riverine export of aged terrestrial organic matter to the North Atlantic Ocean. Nature 409, 497-500 (2001).

46. Van Oost, K. et al. Landscape-scale modeling of carbon cycling under the impact of soil redistribution: The role of tillage erosion. Global Biogeochem Cy 19, GB4014; DOI:10.1029/2005GB002471 (2005).

47. Mayorga, E. et al. Young organic matter as a source of carbon dioxide outgassing from Amazonian rivers. Nature 436, 538-541 (2005).

48. Abril, G. et al. Amazon River carbon dioxide outgassing fuelled by wetlands. Nature 505, 395-398 (2013).

49. Glay, V. et al. Efficient organic carbon burial in the Bengal fan sustained by the Himalayan erosional system. Nature 450, 407-410 (2007).

50. Bauer, J. E. et al. The changing carbon cycle of the coastal ocean. Nature 504, 61-70 (2013).

51. Yan, H., Wang, S., Wang, C., Zhang, G. \& Patel, N. Losses of soil organic carbon under wind erosion in China. Global Change Biol 11, 828-840 (2005).

52. Nie, X., Zhang, J. \& Su, Z. Dynamics of soil organic carbon and microbial biomass carbon in relation to water erosion and tillage erosion. PLOS ONE 8, e64059; DOI:10.1371/journal.pone.0064059 (2013).

53. Yan, J. H. et al. Carbon uptake by karsts in the Houzhai Basin, Southwest China. J Geophys Res 116, Doi:10.1029/2011JG001686 (2011).

54. Jiang, Z. \& Yuan, D. $\mathrm{CO}_{2}$ source-sink in karst processes in karst areas of China. Episodes 22, 33-35 (1999).

55. Parveen, R. \& Kumar, U. Integrated approach of Universial Soil Loss Equation (USLE) and Geographical Information System (GIS) for soil loss risk assessment in upper south Koel Basin, Jharkhand. J Geogr Inf Syst 4, 588-596 (2012).

56. Warren, S. D., Diersing, V. E., Thompson, P. J. \& Goran, W. D. An erosion-based land classification system for military installations. Environ Manage 13, 251-257 (1989).

57. Zhou, P., Luukkanen, O., Tokola, T. \& Nieminen, J. Effect of vegetation cover on soil erosion in a mountainous watershed. Catena 75, 319-325 (2008).

58. 53Renard, K. G. \& Freimund, J. R. Using monthly precipitation data to estimate the R-factor in the revised USLE. J Hydrol 157, 287-306 (1994).

59. Sharpley, A. N. \& Williams, J. R. EPIC-Erosion/Productivity Impact Calculator. 1. Model documentation. USDA Technical Bulletin 1768, 235 (1990).

60. Van Remortel, R. D., Maichle, R. W. \& Hickey, R. J. Computing the LS factor for the Revised Universal Soil Loss Equation through array-based slope processing of digital elevation data using a C ++ executable. Comput Geosci-UK 30, 1043-1053 (2004).

61. Yang, Y. S. \& Shi, D. M. Study on Soil Erosion in the Three Gorge Area of the Changjiang River (Southeast University Press, Nanjing, 1994). (In Chinese)

62. Schönbrodt, S., Saumer, P., Behrens, T., Seeber, C. \& Scholten, T. Assessing the USLE crop and management factor $\mathrm{C}$ for soil erosion modeling in a large mountainous watershed in central China. J Earth Sci-China 21, 835-845 (2010).

63. Wu, L., Long, T., Liu, X. \& Ma, X. Modeling impacts of sediment delivery ratio and land management on absorbed non-point source nitrogen and phosphorus load in mountainous basin of the Three Gorges reservoir area, China. Environ Earth Sci 70, 1405-1422 (2013)

64. Yuan, W. P. et al. Validation of China-wide interpolated daily climate variables from 1960 to 2011. Theor Appl Climatol DOI:10.1007/s00704-014-1140-0 (2014)

65. Shang-Guan, W., Dai, Y. J., Liu, B. Y., Ye, A. Z. \& Yuan, H. A soil particle-size distribution dataset for regional land and climate modelling in China. Geoderma 171-172, 85-91 (2012).

66. Polyakov, V. \& Lal, R. Modeling soil organic matter dynamics as affected by soil water erosion. Environ Int 30, 547-556 (2004).

67. Lal, R. Soil carbon sequestration to mitigate climate change. Geoderma, 123, 1-22 (2004).

68. Beyer, L., Köbbemann, C., Finnern, J., Elsner, D. \& Schlu $\beta$, W. Colluvisols under cultivation in Schleswig-Holstein, 1: Genesis, definition and geoecological significance. J Plant Nutr Soil Sc 156, 197-202 (1993).

69. Chapot, V. \& Poesen, J. Sediment, soil organic carbon and runoff delivery at various spatial scales. Catena 88, 46-56 (2012).

70. Starr, G. C. et al. Modeling soil carbon transported by water erosion processes. Land Degrad Dev 11, 83-91 (2000).

71. Doetterl, S., Six, J., Wesemael, B. \& Van Oost, K. Carbon cycling in eroding landscapes: geomorphic controls on soil organic $\mathrm{C}$ pool composition and $\mathrm{C}$ stabilization. Global Change Biol 18, 2218-2232 (2012).

\section{Acknowledgments}

This study was supported by the National Natural Science Foundation of China (41201078), National Science Foundation for Excellent Young Scholars of China (41322005), and Program for New Century Excellent Talents in University (NCET-12-0060).

\section{Author contributions}

W.Y., H.Z. and W.D. designed the study. H.Z. and W.Y. wrote the main manuscript text S.L., A.Y., X.X. and D.L. modified the manuscript. H.Z., W.Y., Y.C., W.C. and Y.M. processed and analyzed the data. All authors reviewed the manuscript.

\section{Additional information}

Supplementary information accompanies this paper at http://www.nature.com/ scientificreports

Competing financial interests: The authors declare no competing financial interests.

How to cite this article: Zhang, H. et al. Inclusion of soil carbon lateral movement alters terrestrial carbon budget in China. Sci. Rep. 4, 7247; DOI:10.1038/srep07247 (2014)

This work is licensed under a Creative Commons Attribution-NonCommercialShareAlike 4.0 International License. The images or other third party material in this article are included in the article's Creative Commons license, unless indicated otherwise in the credit line; if the material is not included under the Creative Commons license, users will need to obtain permission from the license holder in order to reproduce the material. To view a copy of this license, visit http:// creativecommons.org/licenses/by-nc-sa/4.0/ 